\title{
Chronic pulsatile infusion of growth hormone to growth-restricted fetal sheep increases circulating fetal insulin-like growth factor-I levels but not fetal growth
}

\author{
M K Bauer, B B Breier, F H Bloomfield, E C Jensen, \\ P D Gluckman and J E Harding
}

The Liggins Institute, Faculty of Medical and Health Science, University of Auckland, Private Bag 92019, Auckland, New Zealand

(Requests for offprints should be addressed to J E Harding; Email: j.harding@auckland.ac.nz)

(M K Bauer is now at Novo Nordisk A/S, Pharmacological Research 3, Novo Nordisk Park, DK-2760 Maaloev, Denmark)

\begin{abstract}
Intra-uterine growth restriction (IUGR) is a major cause of perinatal mortality and morbidity. Postnatally, growth hormone $(\mathrm{GH})$ increases growth, increases circulating insulin-like growth factor (IGF)-I levels, and alters metabolism. Our aim was to determine if GH infusion to IUGR fetal sheep would alter fetal growth and metabolism, and thus provide a potential intra-uterine treatment for the IUGR fetus.

We studied three groups of fetuses: control, IUGR+ vehicle and IUGR $+\mathrm{GH}$ ( $n=5$ all groups). IUGR was induced by repeated embolisation of the placental vascular bed between 110 and 116 days of gestation (term $=145$ days). GH $(3.5 \mathrm{mg} / \mathrm{kg} /$ day $)$ or vehicle was infused in a pulsatile manner from 117 to 127 days of gestation.

Embolisation reduced fetal growth rate by $25 \%$ $(P<0 \cdot 01)$ and reduced the weight of the fetal liver $(20 \%)$, kidney $(23 \%)$ and thymus $(31 \%$; all $P<0 \cdot 05)$. GH treatment further reduced the weight of the fetal kidneys $(32 \%)$ and small intestine (35\%; both $P<0 \cdot 04)$, but restored the relative weight of the fetal thymus and liver $(P<0 \cdot 05)$. Embolisation decreased fetal plasma IGF-I concentrations $(48 \%, P<0 \cdot 001)$ and increased IGF binding protein 1
\end{abstract}

(IGFBP-1) concentrations $(737 \%, P<0 \cdot 002)$. GH treatment restored fetal plasma IGF-I concentrations to control levels, while levels in IUGR+vehicle fetuses stayed low $(P<0.05$ vs control). IGFBP-1 and IGFBP-2 concentrations were about sevenfold lower in amniotic fluid than in fetal plasma, but amniotic and plasma concentrations were closely correlated $(r=0.75, P<0.0001$ and $r=0.55 P<0.0001$ respectively). Embolisation transiently decreased fetal blood oxygen content $(40 \%, P<0 \cdot 002)$, and increased blood lactate concentrations $(213 \%, P<0 \cdot 04)$. Both returned to pre-embolisation levels after embolisation stopped, but blood glucose concentrations declined steadily in IUGR+vehicle fetuses. GH treatment maintained fetal blood glucose concentrations at control levels.

Our study shows that GH infusion to the IUGR fetal sheep restores fetal IGF-I levels but does not improve fetal growth, and further reduces the fetal kidney and intestine weights. Thus, fetal GH therapy does not seem a promising treatment stratagem for the IUGR fetus.

Journal of Endocrinology (2003) 177, 83-92

\section{Introduction}

Intra-uterine growth restriction (IUGR) is a major cause of perinatal mortality and morbidity. To date there is no available treatment for fetuses in utero who are identified as growth restricted but are not sufficiently mature for safe delivery.

Insulin-like growth factor (IGF)-I has been shown to be a major growth factor during fetal life (Baker et al. 1993, Liu et al. 1993) and umbilical cord blood IGF-I concentrations are positively correlated with size at birth (Gluckman et al. 1992b). IGF-I infusion beyond an experimentally induced oesophageal atresia in fetal sheep, calculated to replace the amount of IGF-I otherwise swallowed, prevented somatic and gastrointestinal growth restriction seen in saline-treated fetuses (Kimble et al. 1999). IGF-I infusion for 10 days to normally growing fetal sheep also increased growth of the visceral organs, although not of the muscles and long bones (Lok et al. 1996). The effects of long-term systemic IGF-I infusion in IUGR fetuses have not been described. However, a 10-day intra-amniotic IGF-I supplementation in IUGR fetal sheep restored small gut weight, but reduced spleen, liver and thymus weights (Bloomfield et al. 2002a), while promoting gut utilisation of amino acids from the amniotic fluid pool (Bloomfield et al. 2002c). 
In postnatal life, circulating IGF-I levels are primarily regulated by $\mathrm{GH}$. The role of fetal $\mathrm{GH}$ in fetal growth and metabolism is less well understood. The traditional view has been that $\mathrm{GH}$ has little role in the regulation of fetal IGF-I levels or of fetal growth. Fetal lambs made GH deficient by hypophysectomy have normal birth weights and have only mildly reduced circulating IGF-I concentrations (Mesiano et al. 1987, 1989). Fetal GH receptor concentrations in liver are only about 30\% of adult concentrations (Klempt et al. 1993) and plasma GH concentrations are 10- to 20-fold higher during fetal life than postnatally, while circulating fetal IGF-I concentrations are relatively low (de Zegher et al. 1988). Immediately after birth $\mathrm{GH}$ receptor concentrations and plasma IGF-I levels increase rapidly, while plasma GH levels drop to adult levels (Breier et al. 1994). The interpretation of these observations has been that the fetal somatotrophic axis is immature until after birth.

However, there is growing evidence that the fetal somatotrophic axis is functional before birth. Fetal $\mathrm{GH}$ concentrations are regulated by the same factors that regulate $\mathrm{GH}$ concentrations after birth, including undernutrition (Bauer et al. 1995) and the hypothalamic hormones GH-releasing hormone and somatostatin (Gluckman et al. 1979, Gluckman 1984). GH receptor mRNA is present in both hepatic and extra-hepatic tissues in the late gestational fetal sheep (Klempt et al. 1993) and in human fetal chondrocytes and fibroblasts (Werther $e t$ al. 1993). Furthermore, infants born GH deficient have a small but measurable decrease in birth length (Gluckman et al. 1992a). Hypophysectomised fetal sheep have markedly increased fat deposition, which is reversed by fetal GH replacement using a crude pituitary preparation (Stevens \& Alexander 1986). We have shown that a 10-day GH infusion to the normal late-gestational fetal sheep did not alter fetal growth or endocrine parameters that are sensitive to $\mathrm{GH}$ treatment postnatally. However, $\mathrm{GH}$-treated fetuses had lowered blood urea concentrations and reduced fetal glucose uptake per $\mathrm{kg}$ fetus (Bauer $e t$ al. 2000), suggesting that GH may have a role in the regulation of fetal metabolism even in the absence of demonstrable growth or endocrine effects.

In normal sheep, short-term infusion of IGF-I into the maternal or fetal circulations also alters feto-placental metabolism, especially of lactate, suggesting that fetoplacental metabolism can be influenced by maternal and fetal IGF-I levels (Harding et al. 1994, Liu et al. 1994). However, acute IGF-I infusion into IUGR fetuses proved ineffective, raising the possibility that the effects of IGF-I are different in normally growing and IUGR fetuses (Jensen et al. 1999). It is not known if this may also be true for $\mathrm{GH}$.

The aim of this study was, therefore, to determine if additional pulsatile GH infusion would alter fetal growth, endocrine status and metabolism in the growth restricted late-gestational fetal sheep.

\section{Materials and Methods}

\section{Animals}

Fifteen singleton bearing Romney Dorset cross-bred ewes were brought to the laboratory at 95 days of gestation (term $=145$ days). They were housed in individual metabolic cages with free access to water and concentrates. At 106 days ewes underwent surgery as described previously (Harding et al. 1997). In brief, hysterotomy was performed under general halothane anaesthesia. Catheters were placed in the fetal femoral arteries and veins via the tarsal vessels and the common umbilical vein via a paraumbilical incision. Two growth measuring devices ('growth catheters') were placed, one around each half of the fetal chest from sternum to spine as previously described (Harding et al. 1997). Catheters were also placed in the uterine vein via the utero-ovarian vein, the uterine arteries of both uterine horns, maternal carotid and femoral artery as well as the jugular and femoral vein. An amniotic catheter for sampling of amniotic fluid was secured to the fetal hind limb.

Antibiotics (5 ml streptopen; $250 \mathrm{mg}$ procaine penicillin/ $250 \mathrm{mg}$ dihydrostreptomycin sulphate; Pittman Moore Ltd, Upper Hutt, New Zealand) were given intramuscularly to the ewe on the day of surgery and daily for the next 3 days. The fetus received $80 \mathrm{mg}$ gentamicin intravenously on the same occasions. Catheters were flushed every second day with physiological saline containing $10 \mathrm{IU}$ heparin $/ \mathrm{ml}$. Growth catheters were measured twice daily after the ewe had been standing quietly for several minutes and the mean of the two measurements was recorded.

At the end of the experiment ewes were killed with an overdose of pentobarbitone and the uterus and its contents were dissected, weighed and measured. The position of the catheters was confirmed. All animal experiments were approved by the Animal Ethics Committee of the University of Auckland.

\section{Experimental procedures}

After a 3-day recovery period from surgery (= experimental day 0) ewes were randomly assigned to three treatment groups: (i) control: no placental embolisation followed by 11-day vehicle infusion to the fetus, (ii) IUGR+vehicle: placental embolisation followed by 11-day vehicle infusion to the fetus, (iii) IUGR +GH: placental embolisation followed by 11-day pulsatile GH infusion to the fetus.

IUGR was induced between experimental day 0 and 6 (110-116 days of gestation) by embolisation of the placental vascular bed as previously described (Jensen et al. 1999, Bloomfield et al. 2002a). In brief, $30000024-44 \mu \mathrm{m}$ beads ( 150000 beads $/ \mathrm{ml}$; Superdex 30 diluted in phosphate buffered saline $\mathrm{pH} 7.5$; Pharmacia Biotech AB, Uppsala, Sweden) were injected into each uterine artery in the morning and the afternoon for the first 2 days. 
Table 1 Maternal and fetal size at surgery. Data represent means \pm S.E.M., $n=5 /$ group

\begin{tabular}{|c|c|c|c|}
\hline & Control & IUGR + vehicle & IUGR + GH \\
\hline \multicolumn{4}{|l|}{ Parameter } \\
\hline Maternal weight (kg) & $57 \cdot 7 \pm 2 \cdot 8$ & $64 \cdot 5 \pm 3 \cdot 4$ & $61 \cdot 6 \pm 2 \cdot 5$ \\
\hline Fetal hind limb length $(\mathrm{cm})$ & $23 \cdot 3 \pm 0 \cdot 5$ & $23 \cdot 4 \pm 0 \cdot 5$ & $23 \cdot 7 \pm 0 \cdot 4$ \\
\hline Fetal hock-hoof length $(\mathrm{cm})$ & $12 \cdot 3 \pm 0 \cdot 1$ & $11 \cdot 9 \pm 0 \cdot 3$ & $12 \cdot 1 \pm 0 \cdot 1$ \\
\hline Fetal chest girth $(\mathrm{cm})$ & $23 \cdot 2 \pm 0 \cdot 8$ & $23 \cdot 4 \pm 0 \cdot 8$ & $22 \cdot 8 \pm 0 \cdot 7$ \\
\hline
\end{tabular}

Thereafter, the frequency and the volume were titrated against fetal arterial $\mathrm{pO}_{2}$, fetal blood lactate concentrations and increment in fetal girth. Embolisation was stopped if (a) fetal arterial $\mathrm{pO}_{2}<14 \mathrm{mmHg}$ and/or (b) fetal blood lactate $>2.5 \mathrm{mmol} / 1$ and/or (c) growth catheters showed no growth for 2 days.

Intravenous infusions were started on experimental day 7 and continued until day 17 (117-127 days of gestation). GH (recombinant bovine GH, batch PR003; American Cyanamid, Princeton, NJ, USA) was dissolved freshly each day in carbonate buffered saline, $\mathrm{pH} 9 \cdot 4(145 \mathrm{mM}$ $\left.\mathrm{NaCl}, 31.5 \mathrm{mM} \mathrm{NaHCO}_{3}, 10.7 \mathrm{mM} \mathrm{Na}_{2} \mathrm{CO}_{3}\right)$. The total daily dose of $\mathrm{GH}$ was $3.5 \mathrm{mg}$. The $\mathrm{GH}$ infusion consisted of two components: a continuous infusion at $1 \mathrm{ml} / \mathrm{h}$ delivering $2.5 \mathrm{mg} /$ day and 30 superimposed $\mathrm{GH}$ pulses at $330 \mu \mathrm{l} /$ pulse delivering $1 \mathrm{mg} /$ day. This infusion pattern mimics the natural secretion pattern of $\mathrm{GH}$ in fetal sheep of similar gestational age (Bauer et al. 1995, 2000). Vehicle-infused fetuses received an identical volume of carbonate buffered saline.

Arterial blood samples from the ewe $(4 \mathrm{ml})$ and fetus $(2 \mathrm{ml})$ and amniotic fluid samples $(2 \mathrm{ml})$ were taken for endocrine and metabolic measurements immediately before the first embolisation and on alternate days thereafter in the morning before any other manipulation of the animal.

Assays

Glucose, lactate and urea were measured by standard enzymatic colorimetric methods modified for 96-well plates as previously described (Bauer et al. 1995). Amino-nitrogen was assayed by colorimetric reaction with $\beta$-naphthaquinone sulphonate (Evans et al. 1993). Antipyrine was measured by HPLC (Pimentel et al. 1986). 3-O-[methyl $\left.{ }^{3} \mathrm{H}\right]$ glucose and $\left[{ }^{14} \mathrm{C}\right]$ urea activities were measured in duplicate in blood deproteinised with sulphuric acid and sodium tungstate and counted on a dual channel liquid scintillation counter (Rack beta model 1219, LKB Wallac, Turku, Finland) with external quench correction for $10 \mathrm{~min}$ or until the d.p.m. error was less than $3 \%$.

The methods for measurement of IGFs and IGF-binding proteins (IGFBP) were developed and validated for ovine plasma in our laboratory and have been published pre- viously. IGF-I was assayed using an IGFBP blocked RIA validated for ovine plasma and amniotic fluid (Bennet et al. 2001, Bloomfield et al. 2002b). IGF-II was measured by RIA after acid-ethanol extraction and addition of access IGF-I to eliminate interference with residual IGFBPs (Bennet et al. 2001). Ovine IGFBP-1 and IGFBP-2 were analysed by specific RIAs developed and validated for sheep plasma and amniotic fluid as described previously (Gallaher et al. 1995, Bennet et al. 2001).

\section{Statistical analysis}

Statistical analysis of data was performed using JMP (SAS Institute Inc, Cary, NC, USA). The effects of embolisation before the onset of treatment were analysed using repeated measures multiple ANOVA (MANOVA) computing only data from experimental days 0-6. Comparisons during the treatment period were made by repeated measures MANOVA computing only data obtained between experimental days 7 and 16 with embolisation as main effect (comparing control with all embolised fetuses) and with treatment as nested effect within embolisation (comparing embolised fetuses treated with vehicle or $\mathrm{GH}$ ). Post-mortem data were analysed using ANOVA with embolisation as main effect and treatment as nested effect within embolisation. Spearman's Rho correlation coefficients were calculated when comparing plasma and amniotic fluid concentrations. A $P$ value equal or less than $0 \cdot 05$ was considered statistically significant. All data are presented as means \pm S.E.M.

\section{Results}

Effect of placental embolisation and GH treatment on fetal growth

Fetal and maternal morphometric data were not different between the groups at the time of surgery (Table 1). Embolisation slowed fetal growth (Fig. 1). Control fetuses grew steadily throughout the experimental period $(2.6 \mathrm{~mm} /$ day), while growth slowed in embolised fetuses between experimental days 4 and $7(1.3 \mathrm{~mm} /$ day; MANOVA time $\times$ embolisation $P<0 \cdot 03)$ and then resumed at a lower trajectory (control: $2.6 \mathrm{~mm} /$ day, 


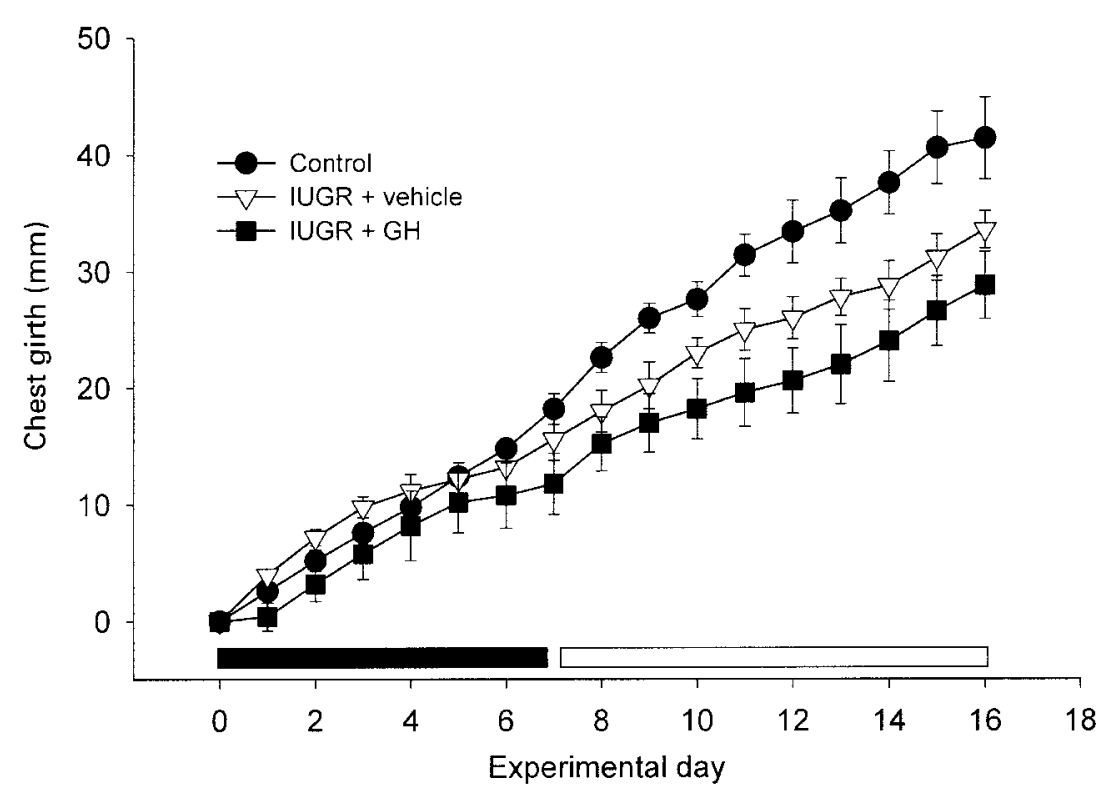

Figure 1 Fetal chest girth increments. Fetal growth slowed towards the end of the placental embolisation period, indicated by the black bar (MANOVA, time $\times$ embolisation, $P<0 \cdot 03$ ). Fetal growth resumed during the infusion period (open bar); this was, however, at a lower trajectory compared with control (MANOVA, $P<0 \cdot 01)$.

IUGR+vehicle: $2 \mathrm{~mm} /$ day, IUGR+GH: $1.9 \mathrm{~mm} /$ day; MANOVA control vs embolised, $P<0 \cdot 01)$. This slowed growth resulted in embolised fetuses that were thinner $(P<0 \cdot 05)$ and tended to be shorter $(P<0 \cdot 07)$ and lighter $(P<0 \cdot 09)$ at post-mortem (Table 2$)$. Fetal thymus, liver and kidney weights were reduced by $31 \%, 20 \%$ and $23 \%$ respectively $(P<0 \cdot 04)$, and there was a trend towards reduced weight of the fetal brain, thyroid and heart $(P<0 \cdot 06)$. Only thymus weight was significantly reduced relative to body weight $(P<0 \cdot 03$, Table 2$)$.

$\mathrm{GH}$ infusion did not restore overall fetal growth (Fig. 1 and Table 2). However, it did normalise the weights of the fetal liver and thymus $(P<0 \cdot 05)$. In contrast, both absolute and relative weights of the kidney and small intestine were further reduced $(P<0 \cdot 05)$ and there was a trend towards reduction in hock-hoof length $(P<0 \cdot 06)$ and absolute and relative weight of the large intestine $(P<0 \cdot 09$, Table 2).

\section{Fetal and maternal endocrine parameters}

Embolisation reduced fetal IGF-I concentrations, although there was some recovery after embolisation ceased (days 4-6) (Fig. 2, MANOVA control vs embolised, $P<0 \cdot 001$ ). GH infusion gradually increased plasma IGF-I concentrations in IUGR $+\mathrm{GH}$ fetuses, to reach control levels by day 6 of infusion, while concentrations in IUGR+vehicle fetuses remained low for the rest of the experiment (Fig. 2, MANOVA, time $\times$ treatment $P<0 \cdot 05)$. Amniotic fluid IGF-I concentrations were 10- to 20-fold lower than plasma levels and did not change with embolisation or GH infusion (control: $3 \cdot 6 \pm 0 \cdot 7$, IUGR+vehicle: $4 \cdot 1 \pm$ $0 \cdot 7$, IUGR $+\mathrm{GH}: 4 \cdot 9 \pm 0 \cdot 6 \mathrm{ng} / \mathrm{ml})$.

Fetal plasma IGF-II concentrations were significantly higher in fetuses allocated to the IUGR $+\mathrm{GH}$ group before the onset of embolisation (day 0: control: $551 \pm 58 \mathrm{ng} / \mathrm{ml}$, IUGR+vehicle: $562 \pm 59$, IUGR+GH: $891 \pm 92 \mathrm{ng} / \mathrm{ml}$, ANOVA, $P<0 \cdot 01)$ and remained higher in this group compared with the other two groups throughout the experiment (MANOVA, $P<0 \cdot 02$ ). There was no effect of embolisation or GH infusion on fetal IGF-II plasma concentrations.

Embolisation elevated fetal plasma IGFBP-1 concentrations sevenfold (Fig. 3, MANOVA, $P<0 \cdot 002$ ), but these returned to control levels after embolisation ceased. GH infusion tended to increase fetal IGFBP-1 concentrations transiently (days 3-7 of GH infusion), but concentrations returned to control levels by the end of the experiment (Fig. 3, MANOVA, $P<0 \cdot 1$ ). Amniotic fluid IGFBP-1 concentrations were approximately sevenfold lower than plasma concentrations, but reflected very closely plasma IGFBP-1 fluctuations in all groups throughout the experiment $(r=0 \cdot 75, P<0 \cdot 0001)$.

Embolisation did not alter fetal plasma IGFBP-2 concentrations (Fig. 4). However, GH infusion gradually increased IGFBP-2 concentrations (MANOVA, $P<0 \cdot 04$ ). IGFBP-2 concentrations measured in amniotic fluid were approximately eightfold lower than in plasma, but again reflected closely plasma IGFBP-2 fluctuations in all groups $(r=0 \cdot 55, P<0 \cdot 0001)$. 
Table 2 Absolute and relative fetal size and organ weight at post-mortem. Values are means \pm S.E.M., $n=5 /$ group

\begin{tabular}{|c|c|c|c|}
\hline & Control & IUGR + vehicle & IUGR+GH \\
\hline \multicolumn{4}{|l|}{ Parameter } \\
\hline Crown rump length $(\mathrm{cm})$ & $43 \cdot 2 \pm 1 \cdot 5$ & $40 \cdot 8 \pm 0 \cdot 8$ & $40 \cdot 4 \pm 0 \cdot 6$ \\
\hline Hind limb length $(\mathrm{cm})$ & $31 \cdot 0 \pm 0 \cdot 9$ & $30 \cdot 9 \pm 0 \cdot 9$ & $29 \cdot 7 \pm 0 \cdot 9$ \\
\hline Hock-hoof length $(\mathrm{cm})$ & $17 \cdot 0 \pm 0 \cdot 7$ & $17 \cdot 2 \pm 0 \cdot 4$ & $15 \cdot 4 \pm 0 \cdot 8$ \\
\hline Chest girth $(\mathrm{cm})$ & $33 \cdot 7 \pm 0 \cdot 5^{*}$ & $32 \cdot 4 \pm 0 \cdot 8$ & $31 \cdot 7 \pm 0 \cdot 4$ \\
\hline Fetal weight (g) & $3881 \pm 165$ & $3501 \pm 260$ & $3342 \pm 151$ \\
\hline Brain (g) & $49 \cdot 5 \pm 0 \cdot 9$ & $46 \cdot 8 \pm 2 \cdot 0$ & $44 \cdot 8 \pm 1 \cdot 4$ \\
\hline Brain (\% BW) & $1 \cdot 3 \pm 0 \cdot 06$ & $1 \cdot 3 \pm 0 \cdot 11$ & $1 \cdot 3 \pm 0 \cdot 04$ \\
\hline Thyroid (g) & $1 \cdot 3 \pm 0 \cdot 1$ & $0 \cdot 9 \pm 0 \cdot 1$ & $1 \cdot 1 \pm 0 \cdot 1$ \\
\hline Thyroid (\% BW) & $0.03 \pm 0.003$ & $0.02 \pm 0.002$ & $0.03 \pm 0.005$ \\
\hline Thymus (g) & $16 \cdot 4 \pm 1 \cdot 3^{* *}$ & $9 \cdot 9 \pm 1 \cdot 6$ & $12 \cdot 6 \pm 1 \cdot 6^{\#}$ \\
\hline Thymus (\% BW) & $0 \cdot 43 \pm 0 \cdot 04^{*}$ & $0 \cdot 28 \pm 0 \cdot 04$ & $0.37 \pm 0.03$ \\
\hline Heart (g) & $32 \cdot 4 \pm 1 \cdot 4$ & $27 \cdot 3 \pm 1 \cdot 7$ & $29 \cdot 3 \pm 1 \cdot 7$ \\
\hline Heart (\% BW) & $0 \cdot 8 \pm 0 \cdot 01$ & $0 \cdot 8 \pm 0 \cdot 01$ & $0.9 \pm 0.06$ \\
\hline Lung (g) & $89 \cdot 2 \pm 3 \cdot 3$ & $98 \cdot 6 \pm 5 \cdot 6$ & $84 \cdot 5 \pm 9 \cdot 7$ \\
\hline Lung (\% BW) & $2 \cdot 3 \pm 0 \cdot 1$ & $2 \cdot 8 \pm 0 \cdot 1$ & $2 \cdot 5 \pm 0 \cdot 2$ \\
\hline Liver (g) & $153 \pm 11^{* *}$ & $112 \pm 8$ & $132 \pm 5$ \\
\hline Liver (\% BW) & $4 \cdot 0 \pm 0 \cdot 2$ & $3 \cdot 2 \pm 0 \cdot 3$ & $4 \cdot 0 \pm 0 \cdot 3^{\#}$ \\
\hline Spleen $(\mathrm{g})$ & $8 \cdot 9 \pm 1 \cdot 1$ & $8 \cdot 3 \pm 0 \cdot 6$ & $6 \cdot 7 \pm 0 \cdot 6$ \\
\hline Spleen (\% BW) & $0 \cdot 2 \pm 0 \cdot 02$ & $0 \cdot 2 \pm 0.03$ & $0 \cdot 2 \pm 0 \cdot 01$ \\
\hline Kidney (g) & $34 \cdot 5 \pm 3 \cdot 5^{*}$ & $31 \cdot 7 \pm 3 \cdot 3$ & $21 \cdot 4 \pm 1 \cdot 0^{\#}$ \\
\hline Kidney (\% BW) & $0.89 \pm 0.06$ & $0.90 \pm 0.04$ & $0.64 \pm 0.04^{\# \#}$ \\
\hline Adrenal (g) & $0.5 \pm 0.03$ & $0.5 \pm 0.08$ & $0.5 \pm 0.05$ \\
\hline Stomach $(\mathrm{g})$ & $59 \cdot 2 \pm 6 \cdot 4$ & $57 \cdot 7 \pm 16 \cdot 2$ & $35 \cdot 7 \pm 5 \cdot 5$ \\
\hline Stomach (\% BW) & $1 \cdot 5 \pm 0 \cdot 1$ & $1 \cdot 5 \pm 0.3$ & $1 \cdot 1 \pm 0 \cdot 1$ \\
\hline Small intestine $(\mathrm{g})$ & $73 \cdot 4 \pm 6 \cdot 2$ & $80 \cdot 0 \pm 16 \cdot 2$ & $49 \cdot 4 \pm 2 \cdot 2^{\#}$ \\
\hline Small intestine (\% BW) & $1.9 \pm 0.08$ & $2 \cdot 2 \pm 0 \cdot 34$ & $1 \cdot 5 \pm 0 \cdot 4^{\#}$ \\
\hline Small intestine $(\mathrm{cm})$ & $602 \pm 36$ & $571 \pm 6$ & $550 \pm 23$ \\
\hline Large intestine $(\mathrm{g})$ & $26 \cdot 0 \pm 2 \cdot 9$ & $25 \cdot 3 \pm 2 \cdot 4$ & $17 \cdot 9 \pm 0 \cdot 5$ \\
\hline Large intestine (\% BW) & $0.7 \pm 0.09$ & $0 \cdot 7 \pm 0.04$ & $0.5 \pm 0.03$ \\
\hline Large intestine $(\mathrm{cm})$ & $136 \pm 34$ & $106 \pm 7$ & $92 \pm 5$ \\
\hline Placenta $(\mathrm{g})$ & $517 \pm 65^{*}$ & $383 \pm 51$ & $360 \pm 32$ \\
\hline Placentomes $(n)$ & $77 \cdot 8 \pm 4 \cdot 1$ & $64 \cdot 8 \pm 7 \cdot 4$ & $77 \cdot 6 \pm 6 \cdot 5$ \\
\hline Membranes (g) & $286 \cdot 9 \pm 24 \cdot 6$ & $259 \cdot 4 \pm 37 \cdot 5$ & $287.8 \pm 73 \cdot 2$ \\
\hline Uterus (g) & $661 \pm 33$ & $623 \pm 74$ & $568 \pm 49$ \\
\hline
\end{tabular}

Maternal plasma IGF-I, IGF-II, IGFBP-1 and IGFBP-2 concentrations were not different between groups and were not affected by placental embolisation or fetal GH infusion (data not shown).

\section{Fetal and maternal metabolic parameters}

Embolisation decreased fetal blood oxygen content by $40 \%$ within 2 days (Table 3, MANOVA, $P<0 \cdot 002$ ). Fetal blood lactate concentrations rose more slowly, but were doubled by day 4 of embolisation (ANOVA, $P<0 \cdot 04$ ). Fetal blood urea concentrations were higher in embolised than in control fetuses (MANOVA $P<0 \cdot 02$ ). Fetal blood aminonitrogen and glucose concentrations were not affected by embolisation.

IUGR + GH and control fetuses had stable blood glucose concentrations throughout the infusion period, whereas blood glucose concentrations declined steadily in
IUGR+vehicle fetuses (control: 1.09 $\pm 0 \cdot 07$, IUGR+ vehicle: $0.91 \pm 0.14, \quad$ IUGR $+\mathrm{GH}: \quad 1.14 \pm 0.07 \mathrm{mM}$; MANOVA, $P<0 \cdot 01)$. All other fetal blood metabolite concentrations returned to pre-embolisation levels and were not affected by GH treatment.

Maternal blood metabolite concentrations (glucose, lactate, amino-nitrogen and urea) were not different between groups and were not affected by embolisation or fetal GH infusion (data not shown).

\section{Discussion}

The aim of this study was to investigate if exogenous pulsatile GH infusion to the IUGR fetus could alter fetal growth, IGF-I levels and metabolism. We report here for the first time that GH infusion to the IUGR fetal sheep does increase circulating IGF-I concentrations, but does not promote overall fetal growth. On the contrary, 


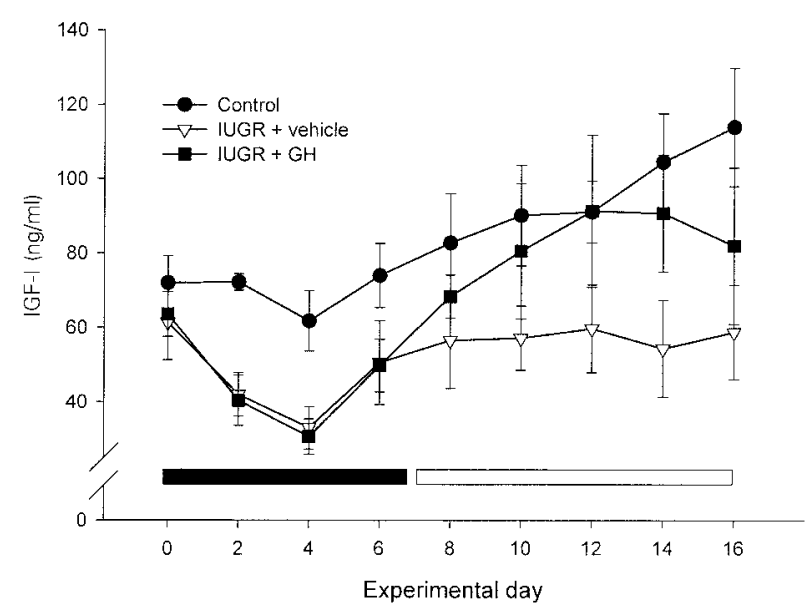

Figure 2 Fetal plasma IGF-I concentrations. Placental embolisation (black bar) reduced IGF-I levels (MANOVA, $P<0 \cdot 001$ ). GH infusion (open bar) gradually increased plasma IGF-I concentrations, while IGF-I levels remained low in the vehicle-infused fetuses (MANOVA, treatment $\times$ time, $P<0 \cdot 05$ ).

treatment of the IUGR fetus with GH further reduces kidney and intestinal weights. We conclude that fetal GH therapy does not seem a promising treatment stratagem for the IUGR fetus.

Our findings are the first clear demonstration of the regulation of fetal plasma IGF-I concentrations by fetal $\mathrm{GH}$, providing further evidence that the fetal somatotrophic axis is functional in utero. We have previously reported that the same fetal GH infusion to normally growing fetal sheep of similar gestational age did not elevate circulating IGF-I concentrations, despite a threefold increase in fetal plasma GH levels (Bauer et al. 2000). The reason for this difference is not clear. It may be that

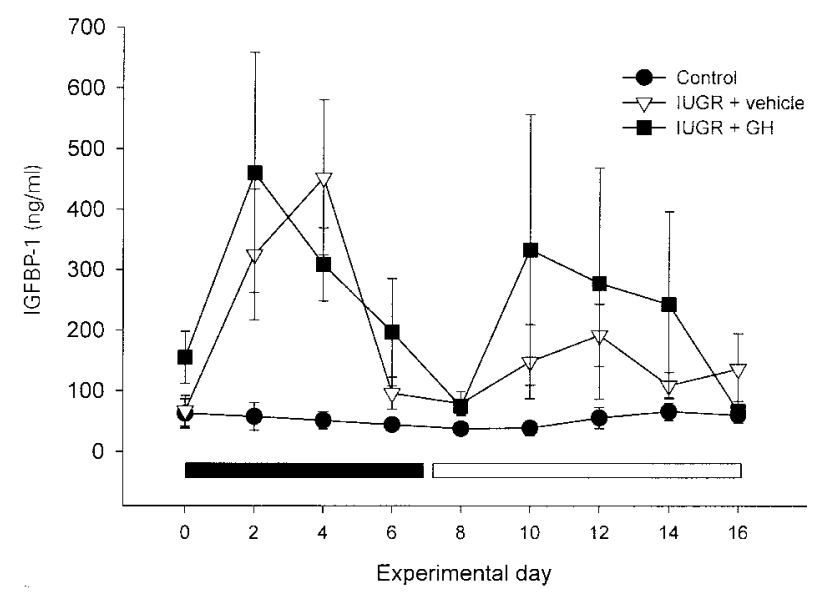

Figure 3 Fetal plasma IGFBP-1 concentrations. Placental embolisation (black bar) elevated IGFBP-1 levels (MANOVA, $P<0 \cdot 002)$, but these returned to control levels after embolisation stopped. GH infusion (open bar) tended to increase IGFBP-1 transiently (MANOVA, $P<0 \cdot 1)$.

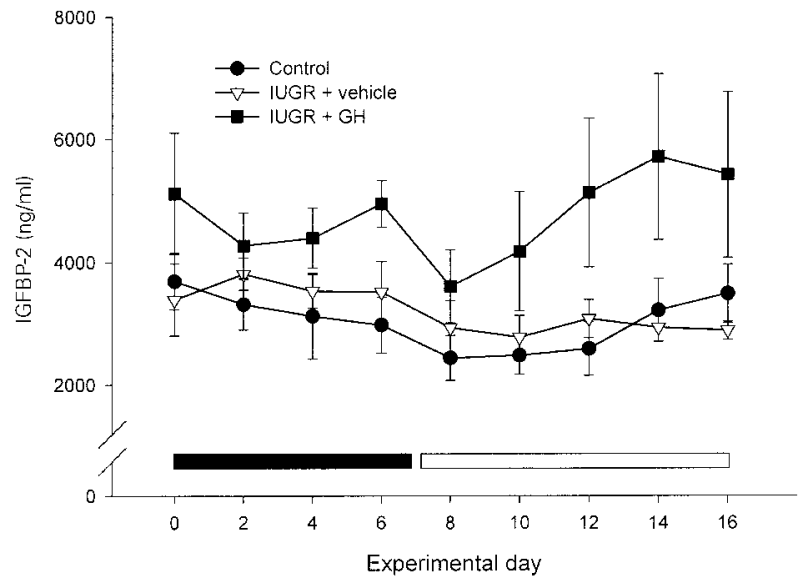

Figure 4 Fetal plasma IGFBP-2 concentrations. Placental embolisation (black bar) did not affect IGFBP-2 levels. GH infusion (open bar) increased IGFBP-2 gradually (MANOVA, $P<0 \cdot 04$ ).

plasma IGF-I levels in normal fetuses are already at their maximum and cannot be stimulated further, whereas IGF-I levels in IUGR fetuses are low and can increase in response to high dose GH treatment. This is supported by our observation that IGF-I levels in GH-infused IUGR fetuses increased to control levels, but not higher. We have not measured fetal GH concentrations in the present experiment. To obtain meaningful GH data one needs to measure GH in frequently taken blood samples (Bauer et al. 1995) and the intense experimental protocol of the present study did not allow for such frequent sampling periods. It seems most likely that fetal GH levels were elevated in embolised fetuses, because chronic undernutrition of the ewe, which leads to reduced substrate supply to the fetus, is accompanied by an increase in fetal GH concentrations (Bauer et al. 1995). Similarly, cord serum GH levels were found to be elevated in smallfor-gestational age infants, both at term and preterm birth (de Zegher et al. 1990). However, GH levels would still have been much lower in IUGR+vehicle than in $\mathrm{IUGR}+\mathrm{GH}$ fetuses.

There is also evidence that the placenta contributes to the regulation of IGF-I levels in the fetus and clears IGF-I from the fetal circulation when levels are high (Bassett et al. 1990, Iwamoto et al. 1992). Thus GH may increase IGF-I levels only in IUGR fetuses before reaching the threshold for placental clearance.

Our hypothesis was that increased fetal IGF-I concentrations would increase fetal growth. IGF-I has been identified as a major fetal anabolic growth factor (Baker et al. 1993, Liu et al. 1993) and has been shown to selectively stimulate organ and bone growth in late gestational fetal sheep following a 10-day infusion (Lok et al. 1996). In our study only relative liver and thymus weights were increased by GH treatment. Both organs have previously been shown to be sensitive to changes in 
Table 3 Fetal metabolites measured in blood samples taken every second day during the embolisation period. Results are means \pm S.E.M., $n=5$ /group. Data are given as $\mathrm{mM}$

\begin{tabular}{|c|c|c|c|c|}
\hline & Day & Control & IUGR + vehicle & IUGR + GH \\
\hline \multicolumn{5}{|l|}{ Parameter } \\
\hline \multirow[t]{3}{*}{ Oxygen** } & 0 & $3 \cdot 69 \pm 0.33$ & $3 \cdot 35 \pm 0 \cdot 35$ & $3 \cdot 40 \pm 0 \cdot 28$ \\
\hline & 2 & $3 \cdot 35 \pm 0.09$ & $1 \cdot 92 \pm 0.36$ & $2 \cdot 12 \pm 0 \cdot 40$ \\
\hline & 4 & $3 \cdot 47 \pm 0 \cdot 20$ & $1 \cdot 90 \pm 0 \cdot 27$ & $2 \cdot 47 \pm 0 \cdot 34$ \\
\hline \multirow[t]{3}{*}{ Lactate $^{\ddagger}$} & 0 & $0.85 \pm 0.09$ & $0.94 \pm 0.03$ & $1 \cdot 25 \pm 0 \cdot 23$ \\
\hline & 2 & $0.96 \pm 0.13$ & $1 \cdot 20 \pm 0.09$ & $1.89 \pm 0.62$ \\
\hline & 4 & $1 \cdot 04 \pm 0.09$ & $1.96 \pm 0.48$ & $2 \cdot 32 \pm 0 \cdot 47$ \\
\hline \multirow[t]{3}{*}{ Glucose } & 0 & $1 \cdot 05 \pm 0.03$ & $1 \cdot 07 \pm 0.05$ & $1 \cdot 35 \pm 0 \cdot 13$ \\
\hline & 2 & $1 \cdot 12 \pm 0 \cdot 07$ & $1 \cdot 07 \pm 0.05$ & $1 \cdot 15 \pm 0 \cdot 10$ \\
\hline & 4 & $1 \cdot 14 \pm 0 \cdot 04$ & $0 \cdot 94 \pm 0 \cdot 10$ & $1 \cdot 14 \pm 0 \cdot 06$ \\
\hline \multirow[t]{3}{*}{ Amino-nitrogen } & 0 & $6 \cdot 13 \pm 0 \cdot 45$ & $6 \cdot 37 \pm 0.43$ & $6 \cdot 71 \pm 0 \cdot 17$ \\
\hline & 2 & $5 \cdot 84 \pm 0 \cdot 27$ & $6 \cdot 04 \pm 0.33$ & $6.95 \pm 0.55$ \\
\hline & 4 & $6 \cdot 12 \pm 0 \cdot 09$ & $7 \cdot 08 \pm 0 \cdot 20$ & $6 \cdot 90 \pm 0.39$ \\
\hline \multirow[t]{3}{*}{ Urea* } & 0 & $3 \cdot 76 \pm 0 \cdot 27$ & $4 \cdot 70 \pm 0 \cdot 36$ & $5 \cdot 71 \pm 0.92$ \\
\hline & 2 & $3 \cdot 98 \pm 0 \cdot 44$ & $6 \cdot 13 \pm 0 \cdot 49$ & $5 \cdot 60 \pm 0.37$ \\
\hline & 4 & $4 \cdot 63 \pm 0.37$ & $5 \cdot 92 \pm 0.54$ & $5 \cdot 56 \pm 0 \cdot 54$ \\
\hline
\end{tabular}

${ }^{*} P<0 \cdot 02,{ }^{*} P<0 \cdot 002$ MANOVA control vs embolised; ${ }^{\ddagger} P<0 \cdot 04$ embolisation $\times$ time interaction.

IGF-I concentrations in the fetus (Bauer et al. 1995, Lok et al. 1996) and during the postnatal period (Singh et al. 1992). The lack of effect on other organs and on overall fetal growth might be due to a change in tissue availability of IGF-I. We found an increase in plasma IGFBP-1 and IGFBP-2 in IUGR +GH fetuses and both IGFBPs have been implicated in the regulation of tissue distribution and the amount of biologically active IGF-I (Baxter 1993, Lee et al. 1997). Transgenic mice overexpressing IGFBP-1 are born small and do not show catch-up growth in postnatal life compared with wild-type mice (Murphy et al. 1995). It is unclear whether $\mathrm{GH}$ infusion in our experiment has directly influenced IGFBP-1 and IGFBP-2 plasma concentrations. Postnatally GH has been shown to suppress IGFBP-1 promoter activity (Lu et al. 1999) and IGFBP-1 secretion (Norrelund et al. 1999). One might, therefore, speculate that the increases in IGFBP-1 and IGFBP-2 are a secondary phenomenon independent of $\mathrm{GH}$. Chronic renal failure patients also have increased IGFBP-1 and IGFBP-2 plasma concentrations, together with a reduction in free plasma IGF-I while total plasma IGF-I levels are normal (Frystyk et al. 1999). Additionally, changes in proteolysis of IGFBPs may have affected the tissue availability of IGF-I. Such changes have been described during human pregnancy (Lassarre \& Binoux 1994), but also during chronic disease states such as insulin-dependent diabetes (Bereket et al. 1999) and renal failure (Frystyk et al. 1999).

The weights of the fetal kidneys and the small and large intestine were further reduced in GH-treated animals. Both findings were totally unexpected, and we have no data on the histology and function of these organs. However, it seems unlikely that such a large reduction in weight would not be accompanied by functional impairment. Both the fetal and postnatal kidney express GH and IGF-receptors (Feld \& Hirschberg 1996, Oliver et al. 1996) and postnatally, kidney growth and function is very sensitive to circulating GH. Compensatory renal growth after unilateral nephrectomy (Flyvbjerg et al. 1999b) and renal hypertrophy in diabetes (Flyvbjerg et al. 1999a) has been shown to be GH dependent and acromegaly and GH therapy are associated with increased glomerular filtration rate and renal plasma flow in man (Ogle et al. 1992). Thus it is difficult to explain our finding of reduced kidney weight with GH treatment. One possible explanation could be a local tissue-specific regulation of IGF-I. Diabetic renal hypertrophy can be inhibited with a specific GH-receptor antagonist, which inhibits local IGF-I production, without affecting circulating levels of IGF-I and GH (Flyvbjerg et al. 1999a).

Alternatively, IUGR is associated with a re-distribution of fetal regional blood flow in experimental animals as well as in humans (Ferrazzi et al. 2001). In fetal sheep it has been shown that acute fetal hypoxia, brought on by umbilical cord occlusion, leads to reduced blood flow in the superior mesenteric artery to shunt blood flow towards vital organs such as the brain and heart (Bennet et al. 2000). Since GH also influences vascular reactivity (Christ et al. 1999), one could speculate that fetal GH treatment may have further decreased blood flow towards the lower abdomen, which would have resulted in an aggravation of kidney and gastro-intestinal growth retardation.

We have previously reported that IUGR induced by placental embolisation (Bloomfield et al. 2002a) or oesophageal ligation (Kimble et al. 1999) in fetal sheep is associated with a reduction in bowel weight and reduced 
fetal growth. These changes were partly reversed by intra-amniotic (Bloomfield et al. 2002a) or enteral IGF-I supplementation (Kimble et al. 1999) respectively. It is interesting to note that enteral IGF-I supplementation did not change fetal plasma IGF-I concentrations, while amniotic IGF-I supplementation actually decreased plasma IGF-I concentrations. In contrast, in the current study systemic fetal IGF-I levels were elevated, but there was a further reduction in small bowel weight. Taken together, these data strongly suggest that the effect of IGF-I on fetal intestinal growth is predominantly a local rather than a systemic effect.

Embolisation reduced fetal plasma IGF-I levels while increasing plasma IGFBP-1 levels sevenfold. Both showed partial recovery when embolisation was stopped. Low IGF-I and high IGFBP-1 levels have been reported previously in the hypoxic fetus (Bennet et al. 2001, McLellan et al. 1992). It is therefore highly likely that the induced hypoxia in our fetuses contributed to the rise in IGFBP-1. Elevated stress hormone levels could also have contributed. Placental embolisation leads to a marked increase in circulating cortisol and noradrenaline in late gestation sheep (Gagnon et al. 1994). Cortisol has been shown to be a powerful stimulator of IGFBP-1 in humans independent of insulin and glucose (Conover et al. 1993). Both postnatally (Lewitt \& Baxter 1990, Nygren et al. 1997) and prenatally (Gallaher et al. 1992), glucose and insulin are thought to be the main regulators of IGFBP-1. In our study, fetal blood glucose levels were not significantly altered during the embolisation period, and are therefore unlikely to be the main regulator of IGFBP-1 in this scenario. However we did not measure plasma insulin levels.

Fetal glucose concentrations steadily declined in IUGR + vehicle fetuses after embolisation was stopped, but remained at control levels in IUGR $+\mathrm{GH}$ animals. Postnatally, GH treatment is associated with impaired glucose metabolism due to GH-induced insulin resistance (Okuda et al. 1994, Johansen et al. 1999). In the fetus insulin plays an important part in the regulation of growth (Fowden et al. 1989), largely by regulating fetal tissue uptake of glucose and amino acids (Fowden et al. 1986, Fowden \& Hay 1988). Thus, one could speculate that fetal GH treatment may have caused insulin resistance, which would have prevented blood glucose levels from declining and also prevented any effect of the increased IGF-I levels on fetal growth.

We found a good correlation between plasma and amniotic fluid levels of both IGFBP-1 and IGFBP-2. The origins of IGFBPs in amniotic fluid are presently unclear, but it is thought that most growth factors in amniotic fluid are of fetal origin (Trahair \& Harding 1994). The close relationship between fetal plasma and amniotic fluid levels in the present study points to the fetus as the source of these proteins. It seems likely that they are contained in fetal urine, tracheal and oronasopharyngeal secretions, which have been shown to contain IGF-I and epidermal growth factor and contribute significantly to the daily amniotic fluid production (Harding et al. 1984, Trahair \& Harding 1994). Alternatively, transmembraneous transport or even an extra-fetal source cannot be entirely ruled out, as there are data that show that the placenta might regulate fetal IGFs (Bassett et al. 1990, Iwamoto et al. 1992).

In summary, we have shown for the first time that fetal $\mathrm{GH}$ infusion to the IUGR fetus can restore circulating IGF-I concentrations. However, this increase in IGF-I did not lead to an improved fetal growth rate. Indeed, the weights of the fetal kidneys and small intestine were further reduced by $\mathrm{GH}$ treatment. Fetal $\mathrm{GH}$ infusion cannot, therefore, be regarded as a possible treatment stratagem for the IUGR fetus.

\section{Acknowledgements}

We thank Dr Mark H Oliver for his expert help with the animal studies. We would also like to acknowledge the excellent technical expertise of Toni Smith-Wong, Pierre L Van Zijl, Christine Keven and Andrezj Surus. Special thanks to Linley Watson and Maree Schollum from the Animal Resources Unit for helping with surgery. This research was supported by the Auckland Medical Research Foundation and the Health Research Council of New Zealand.

\section{References}

Baker J, Liu JP, Robertson EJ \& Efstratiadis A 1993 Role of insulinlike growth factors in embryonic and postnatal growth. Cell 75 $73-82$.

Bassett NS, Breier BH, Hodgkinson SC, Davis SR, Henderson HV \& Gluckman PD 1990 Plasma clearance of radiolabelled IGF-I in the late gestation ovine fetus. Journal of Developmental Physiology 14 73-79.

Bauer MK, Breier BH, Harding JE, Veldhuis JD \& Gluckman PD 1995 The fetal somatotropic axis during long term maternal undernutrition in sheep: evidence for nutritional regulation in utero. Endocrinology 136 1250-1257.

Bauer MK, Harding JE, Breier BH \& Gluckman PD 2000 Exogenous GH infusion to late-gestational fetal sheep does not alter fetal growth and metabolism. Journal of Endocrinology 166 591-597.

Baxter RC 1993 Circulating binding proteins for the insulin-like growth factors. Trends in Endocrinology and Metabolism 4 91-96.

Bennet L, Quaedackers JS, Gunn AJ, Rossenrode S \& Heineman E 2000 The effect of asphyxia on superior mesenteric artery blood flow in the premature sheep fetus. Journal of Pediatric Surgery 35 34-40.

Bennet L, Oliver MH, Gunn AJ, Hennies M \& Breier BH 2001 Differential changes in insulin-like growth factors and their binding proteins following asphyxia in the preterm fetal sheep. Journal of Physiology 531 835-841.

Bereket A, Lang CH \& Wilson TA 1999 Alterations in the growth hormone-insulin-like growth factor axis in insulin dependent diabetes mellitus. Hormone and Metabolic Research 31 172-181.

Bloomfield FH, Bauer MK, Van Zijl PL, Gluckman PD \& Harding JE 2002a Amniotic IGF-I supplements improve gut growth but reduce circulating IGF-I in growth-restricted fetal sheep. American Journal of Physiology, Endocrinology and Metabolism 282 E259-E269. 
Bloomfield FH, Breier BH \& Harding JE 2002b Fate of (125)I-IGF-I administered into the amniotic fluid of late-gestation fetal sheep. Pediatric Research 51 361-369.

Bloomfield FH, Van Zijl PL, Bauer MK \& Harding JE 2002c Effects of intrauterine growth restriction and intraamniotic insulin-like growth factor-I treatment on blood and amniotic fluid concentrations and on fetal gut uptake of amino acids in lategestation ovine fetuses. Journal of Pediatrics Gastroenterology and Nutrition 35 287-297.

Breier BH, Ambler GR, Sauerwein H, Surus A \& Gluckman PD 1994 The induction of hepatic somatotrophic receptors after birth in sheep is dependent on parturition-associated mechanisms. Jourmal of Endocrinology 141 101-108.

Christ ER, Chowienczyk PJ, Sonksen PH \& Russel-Jones DL 1999 Growth hormone replacement therapy in adults with growth hormone deficiency improves vascular reactivity. Clinical Endocrinology 51 21-25.

Conover CA, Divertie GD \& Lee PDK 1993 Cortisol increases plasma insulin-like growth-factor binding protein-1 in humans. Acta Endocrinologica 128 140-143.

Evans PC, Ffolliott-Powell FM \& Harding JE 1993 A colorimetric assay for amino nitrogen in small volumes of blood: reaction with beta-naphthoquinone sulfonate. Annals of Biochemistry 208 334-337.

Feld S \& Hirschberg R 1996 Growth hormone, the insulin-like growth factor system, and the kidney. Endocrine Reviews $\mathbf{1 7}$ 423-480.

Ferrazzi E, Bellotti M, Galan H, Pennati G, Bozzo M, Rigano S \& Battaglia FC 2001 Doppler investigation in intrauterine growth restriction - from qualitative indices to flow measurements: a review of the experience of a collaborative group. Annals of the New York Academy of Sciences 943 316-325.

Flyvbjerg A, Bennett WF, Rasch R, Kopchick JJ \& Scarlett JA 1999a Inhibitory effect of a growth hormone receptor antagonist (G120K-PEG) on renal enlargement, glomerular hypertrophy, and urinary albumin excretion in experimental diabetes in mice. Diabetes 48 377-382.

Flyvbjerg A, Bennett WF, Rasch R, van Neck JW, Groffen CA, Kopchick JJ \& Scarlett JA 1999b Compensatory renal growth in uninephrectomized adult mice is growth hormone dependent. Kidney International 56 2048-2054.

Fowden AL \& Hay WW Jr 1988 The effects of pancreatectomy on the rates of glucose utilization, oxidation and production in the sheep fetus. Quarterly Journal of Experimental Physiology 73 973-984.

Fowden AL, Silver M \& Comline RS 1986 The effect of pancreatectomy on the uptake of metabolites by the sheep fetus. Quarterly Journal of Experimental Physiology 71 67-78.

Fowden AL, Hughes P \& Comline RS 1989 The effects of insulin on the growth rate of the sheep fetus during late gestation. Quarterly Journal of Experimental Physiology 74 703-714.

Frystyk J, Ivarsen P, Skjaerbaek C, Flyvbjerg A, Pedersen EB \& Orskov H 1999 Serum-free insulin-like growth factor I correlates with clearance in patients with chronic renal failure. Kidney International 56 2076-2084.

Gagnon R, Challis J, Johnston L \& Fraher L 1994 Fetal endocrine responses to chronic placental embolization in the late-gestation ovine fetus. American Journal of Obstetrics and Gynecology 170 929-938.

Gallaher BW, Breier BH, Oliver MH, Harding JE \& Gluckman PD 1992 Ontogenic differences in the nutritional regulation of circulating IGF binding proteins in sheep plasma. Acta Endocrinologica 126 49-54.

Gallaher BW, Breier BH, Blum WF, McCutcheon SN \& Gluckman PD 1995 A homologous radioimmunoassay for ovine insulin-like growth factor-binding protein-2: ontogenesis and the response to growth hormone, placental lactogen and insulin-like growth factor-I treatment in sheep. Journal of Endocrinology 144 75-82.
Gluckman PD 1984 Changing responsiveness to growth hormone releasing factor in the perinatal sheep. Journal of Developmental Physiology 6 509-515.

Gluckman PD, Mueller PL, Kaplan SL, Rudolph AM \& Grumbach MM 1979 Hormone ontogeny in the ovine fetus. III. The effect of exogenous somatostatin. Endocrinology 104 974-978.

Gluckman PD, Gunn AJ, Wray A, Cutfield WS, Chatelain PG, Guilbaud O, Ambler GR, Wilton P \& Albertsson-Wikland K $1992 a$ Congenital idiopathic growth hormone deficiency associated with prenatal and early postnatal growth failure. The International Board of the Kabi Pharmacia International Growth Study. Journal of Pediatrics 121 920-923.

Gluckman PD, Gunn AJ, Wray A, Cutfield WS, Chatelain PG, Guilbaud O, Ambler GR, Wilton P \& Albertsson-Wikland K $1992 b$ Congenital idiopathic growth hormone deficiency associated with prenatal and early postnatal growth failure. The International Board of the Kabi Pharmacia International Growth Study. Journal of Pediatrics 121 920-923.

Harding JE, Liu L, Evans PC \& Gluckman PD 1994 Insulin-like growth factor I alters feto-placental protein and carbohydrate metabolism in fetal sheep. Endocrinology 134 1509-1514.

Harding JE, Evans PC \& Gluckman PD 1997 Maternal growth hormone treatment increases placental diffusion capacity but not fetal or placental growth in sheep. Endocrinology $\mathbf{1 3 8}$ $5352-5358$.

Harding R, Bocking AD, Sigger JN \& Wickham PJ 1984 Composition and volume of fluid swallowed by fetal sheep. Quarterly Journal of Experimental Physiology 69 487-495.

Iwamoto HS, Murray MA \& Chernausek SD 1992 Effects of acute hypoxemia on insulin-like growth factors and their binding proteins in fetal sheep. American Journal of Physiology 263 E1151-E1156.

Jensen EC, Harding JE, Bauer MK \& Gluckman PD 1999 Metabolic effects of IGF-I in the growth retarded fetal sheep. Journal of Endocrinology 161 485-494.

Johansen T, Deckert M, Mandrup-Poulsen T \& Malmlof K 1999 The role of growth hormone and glucocorticoid in glucose handling in vivo. Journal of Endocrinology 162 87-93.

Kimble RM, Breier BH, Gluckman PD \& Harding JE 1999 Enteral IGF-I enhances fetal growth and gastrointestinal development in oesophageal ligated fetal sheep. Journal of Endocrinology 162 227-235.

Klempt M, Bingham B, Breier BH, Baumbach WR \& Gluckman PD 1993 Tissue distribution and ontogeny of growth hormone receptor messenger ribonucleic acid and ligand binding to hepatic tissue in the midgestation sheep fetus. Endocrinology 132 1071-1077.

Lassarre C \& Binoux M 1994 Insulin-like growth factor binding protein-3 is functionally altered in pregnancy plasma. Endocrinology 134 1254-1262.

Lee PDK, Giudice LC, Conover CA \& Powell DR 1997 Insulin-like growth factor-binding protein-1 - recent findings and new directions. Proceedings of the Society for Experimental Biology and Medicine 216 319-357.

Lewitt MS \& Baxter RC 1990 Inhibitors of glucose uptake stimulate the production of insulin-like growth factor-binding protein (IGFBP-1) by human fetal liver. Endocrinology 126 1527-1533.

Liu JP, Baker J, Perkins AS, Robertson EJ \& Efstratiadis A 1993 Mice carrying null mutations of the genes encoding insulin-like growth factor I (IGF-I) and type 1 IGF receptor (Igf1r). Cell 75 59-72.

Liu L, Harding JE, Evans PC \& Gluckman PD 1994 Maternal insulin-like growth factor-I infusion alters feto-placental carbohydrate and protein metabolism in pregnant sheep. Endocrinology 135 895-900.

Lok F, Owens JA, Mundy L, Robinson JS \& Owens PC 1996 Insulin-like growth factor I promotes growth selectively in fetal sheep in late gestation. American Journal of Physiology $\mathbf{2 7 0}$ R1148-R1155.

Lu X, Shi Z \& Murphy LJ 1999 Growth hormone suppression of insulin-like growth factor binding protein-1 promoter activity. Molecular and Cellular Endocrinology 149 19-28. 
McLellan KC, Hooper SB, Bocking AD, Delhanty PJ, Phillips ID, Hill DJ \& Han VK 1992 Prolonged hypoxia induced by the reduction of maternal uterine blood flow alters insulin-like growth factor-binding protein-1 (IGFBP-1) and IGFBP-2 gene expression in the ovine fetus. Endocrinology 131 1619-1628.

Mesiano S, Young IR, Baxter RC, Hintz RL, Browne CA \& Thorburn GD 1987 Effect of hypophysectomy with and without thyroxine replacement on growth and circulating concentrations of insulin-like growth factors I and II in the fetal lamb. Endocrinology $1201821-1830$

Mesiano S, Young IR, Hey AW, Browne CA \& Thorburn GD 1989 Hypophysectomy of the fetal lamb leads to a fall in the plasma concentration of insulin-like growth factor I (IGF-I), but not IGF-II. Endocrinology 124 1485-1491.

Murphy LJ, Rajkumar K \& Molnar P 1995 Phenotypic manifestations of insulin-like growth factor binding protein-1 (IGFBP-1) and IGFBP-3 overexpression in transgenic mice. Progress in Growth Factor Research 6 425-432.

Norrelund H, Fisker S, Vahl N, Borglum J, Richelsen B, Christiansen JS \& Jorgensen JO 1999 Evidence supporting a direct suppressive effect of growth hormone on serum IGFBP-1 levels. Experimental studies in normal, obese and GH-deficient adults. Growth Hormone IGF Research 9 52-60.

Nygren J, Thorell A, Brismar K, Karpe F \& Ljungqvist O 1997 Short-term hypocaloric nutrition but not bed rest decrease insulin sensitivity and IGF-I bioavailability in healthy subjects - the importance of glucagon. Nutrition 13 945-951.

Ogle GD, Rosenberg AR \& Kainer G 1992 Renal effects of growth hormone I. Renal function and kidney growth. Pediatric Nephrology 6 394-398.

Okuda Y, Pena J, Chou J \& Field JB 1994 Effect of growth hormone on hepatic glucose and insulin metabolism after oral glucose in conscious dogs. American Journal of Physiology 267 E454-E460.
Oliver MH, Harding JE, Breier BH \& Gluckman PD 1996 Fetal insulin-like growth factor (IGF)-I and IGF-II are regulated differently by glucose or insulin in the sheep fetus. Reproduction, Fertility and Development 8 167-172.

Pimentel G, Figueroa JP, Mitchell MD, Massmann A \& Nathanielsz PW 1986 Effect of fetal and maternal intravascular antipyrine infusion on maternal plasma prostaglandin concentrations in the pregnant sheep at 104 to 127 days' gestation. American Journal of Obstetrics and Gynecology 155 1181-1185.

Singh K, Ambler GR, Breier BH, Klempt M \& Gluckman PD 1992 Ovine placental lactogen is a potent somatogen in the growth hormone (GH)-deficient rat: comparison of somatogenic activity with bovine GH. Endocrinology 130 2758-2766.

Stevens D \& Alexander G 1986 Lipid deposition after hypophysectomy and growth hormone treatment in the sheep fetus. Journal of Developmental Physiology 8 139-145.

Trahair JF \& Harding R 1994 Development of the gastrointestinal tract. In Textbook of Fetal Physiology, pp 219-235. Eds GD Thorburn \& R Harding. Oxford: Oxford University Press.

Werther GA, Haynes K \& Waters MJ 1993 Growth hormone (GH) receptors are expressed on human fetal mesenchymal tissues identification of messenger ribonucleic acid and GH-binding protein. Journal of Clinical Endocrinology and Metabolism 76 1638-1646.

de Zegher F, Bettendorf M, Kaplan SL \& Grumbach MM 1988 Hormone ontogeny in the ovine fetus: XXI. The effect of insulinlike growth factor-I on plasma fetal growth hormone, insulin and glucose concentrations. Endocrinology 123 658-660.

de Zegher F, Kimpen J, Raus J \& Vanderschueren-Lodeweyckx M 1990 Hypersomatotropism in the dysmature infant at term and preterm birth. Biology of the Neonate 58 188-191.

Received 10 December 2002

Accepted 17 December 2002 